\title{
Relationships between distribution of lead in erythrocytes in vivo and in vitro and inhibition of ALA-D
}

\author{
T SAKAI, S YANAGIHARA, Y KUNUGI, AND K USHIO \\ From the Centre of Occupational Medicine, Tokyo Labour Accident Hospital, Ota-Ku, Tokyo 143, Japan
}

ABSTRACT Proteins in the ALA-D ( $\delta$-aminolaevulinic acid dehydratase) fraction from gel filtration of erythrocyte supernatant (ES) have the highest affinity for lead among erythrocyte constituents in vivo and in vitro. It takes $20-40$ hours for erythrocyte components to be equilibrated with lead added in vitro. At low lead concentrations, under $60 \mu \mathrm{g} / 100 \mathrm{ml} \mathrm{ES}$, the extent of ALA-D inhibition correlates with that of lead concentrations in the ALA-D fraction, and the decrease in ALA-D activity indicates the extent of lead saturation of ALA-D fraction proteins. The saturation is attained at $80-110 \mu \mathrm{g} / 100 \mathrm{ml}$ ES. Although an appreciable amount of lead is also found in the haemoglobin fraction that contains certain factors concerned in ALA-D inhibition, lead responsible for inducing the inhibition is not bound to haemoglobin fraction proteins but to ALA-D fraction proteins. Of three treatments or agents recovering the enzyme from lead effects, zinc is the only one that can fully restore the inhibition.

Blood lead concentrations are currently regarded as the most reliable index of exposure to lead. Over $90 \%$ of the blood lead is bound to the erythrocytes and seems to be in dynamic equilibrium with plasma lead. ${ }^{2}$ Plasma lead is more diffusible than erythrocyte lead and more important for evaluating the toxic effect of lead because the diffusible form exerts an influence on lead concentrations of other compartments and produces critical effect in the various organs. ${ }^{1-3}$ Erythrocytes rather behave as a repository for lead, ${ }^{4}$ which might produce some disturbances in erythrocyte metabolism such as $\mathrm{Na}$, $\mathrm{K}$-ATPase, ALA-D ( $\delta$-aminolaevulinic acid dehydratase) activity. ${ }^{56}$

Recently, Ong and $\mathrm{Lee}^{6}$ have reported that more than $85 \%$ of the ${ }^{203} \mathrm{~Pb}$ incorporated into erythrocytes in vitro is associated with the cytoplasmic components and the rest is bound to the stromal membrane. They suggested that the membranebound lead might affect the activity of $\mathrm{Na}$, K-ATPase. Several workers ${ }^{7-9}$ have indicated that most of the labelled lead incorporated into erythrocytes in vitro is found in haemoglobin fractions. By contrast, Sakai et al $^{10}$ reported that half the lead in erythrocyte haemolysate from a lead-exposed worker was found in protein fractions with a high Received 14 September 1981 Accepted 13 October 1981 molecular weight, including ALA-D. There is little information relating to lead-binding components in erythrocytes from a lead-exposed subject so far.

Erythrocyte ALA-D activity is the most sensitive indicator for blood lead concentrations, because the activity is specifically inhibited by lead at concentrations between 20 and $100 \mu \mathrm{g} / 100 \mathrm{~g}$ blood. ${ }^{11-14}$ The highly purified enzyme from human erythrocytes is a homo-octamer with a molecular weight of 252000 and is inhibited by lead at 1 and $5 \mu \mathrm{M}^{15}$; the crude enzyme is also inhibited at a concentration exceeding $1 \mu \mathrm{M} .{ }^{16}$ These concentrations of lead in the reaction mixture are tenfold to fiftyfold higher than those in the mixture containing haemolysate from a lead-exposed worker. Sakai et al ${ }^{10}$ suggested that certain factors detected in the haemoglobin fraction account for this discrepancy between in-vivo and in-vitro activity. As mentioned above, lead is found in the ALA-D fraction and also in the haemoglobin fraction that contains the factors. There are three possibilities in relation to lead inducing ALA-D inhibition; it may be due to lead in ALA-D fraction, lead in the haemoglobin fraction, or both.

To clarify further the nature and the mechanisms of ALA-D inhibition by lead we have investigated the relationships between ALA-D inhibition and the distribution of lead among erythrocyte components in vivo and in vitro. 


\section{Materials and methods}

\section{LEAD BINDING IN VIVO}

Ten millilitres of heparinised venous blood were obtained from workers occupationally exposed to lead and from normal subjects with no history of exposure to lead.

All procedures for fractionating erythrocyte constituents were carried out at $4^{\circ} \mathrm{C}$ as previously described. ${ }^{10}$ Packed erythrocytes from $10 \mathrm{ml}$ of whole blood were washed three times in cooled saline $(0.9 \% \mathrm{NaCl})$ and adjusted to the original haematocrit value with $25 \mathrm{mM}$ phosphate buffer $\mathrm{pH}$ $7 \cdot 0$. Erythrocytes were completely lysed by sonicating. The lysate was centrifuged at $24000 \mathrm{~g}$ for 30 minutes. The erythrocyte supernatant (ES) was applied to a Sephadex G-200 column $(2.6 \times 90 \mathrm{~cm})$ that had been equilibrated with $25 \mathrm{mM}$ phosphate buffer $\mathrm{pH} 7.0$ and eluted with the same buffer. Each fraction was collected in $11 \mathrm{ml}$ (fig 1(a), (b)) or $13 \mathrm{ml}$ (fig 1(c), (d)) aliquots; protein and lead concentrations and ALA-D activity were determined on each aliquot.

Protein concentrations were determined by the absorbance at $280 \mathrm{~nm}$; ALA-D activity was deter- mined by the method of Ushio $e a^{17}$ except that the assay mixture contained $0.5 \mathrm{ml}$ of $0.2 \mathrm{M}$ phosphate buffer $\mathrm{pH} 7.0,0.5 \mathrm{ml}$ of $20 \mathrm{mM}$ ALA $(\delta$ aminolaevulinic acid) solution, $0.5 \mathrm{ml}$ of $50 \mathrm{mM}$ DTT (dithiothreitol), $0.1 \mathrm{ml}$ of the fraction, and $0.9 \mathrm{ml}$ of distilled water; lead concentrations were also determined by the method by Ushio et al, ${ }^{17}$ using flame atomic absorption spectrophotometer.

\section{LEAD-BINDING TO ERYTHROCYTE LYSATE}

Normal erythrocyte lysate was prepared in the way described above, except that $40 \mathrm{mM}$ Tris- $\mathrm{HCl}$ buffer $\mathrm{pH} 7.0$ was used to adjust the volume back to the original haematocrit value. Twenty millilitres of the lysate were added to $2 \mathrm{ml}$ of $25 \mu \mathrm{M}$ lead acetate and incubated at $37^{\circ} \mathrm{C}$. Half the lysate was taken out 5 minutes after the addition of lead, and the rest was incubated for a further 55 minutes and then at $4^{\circ} \mathrm{C}$ for 40 hours. At the end of each incubation the lysate was centrifuged at $24000 \mathrm{~g}$ for 30 minutes. ES thus obtained was applied to a Bio-gel A $1.5 \mathrm{~m}$ column $(2.6 \times 90 \mathrm{~cm})$ that had been equilibrated with $40 \mathrm{mM}$ Tris- $\mathrm{HCl}$ buffer $\mathrm{pH} 7 \cdot 0$ and eluted with the same buffer. ALA-D activity and concentrations of protein and lead in the fractions were determined

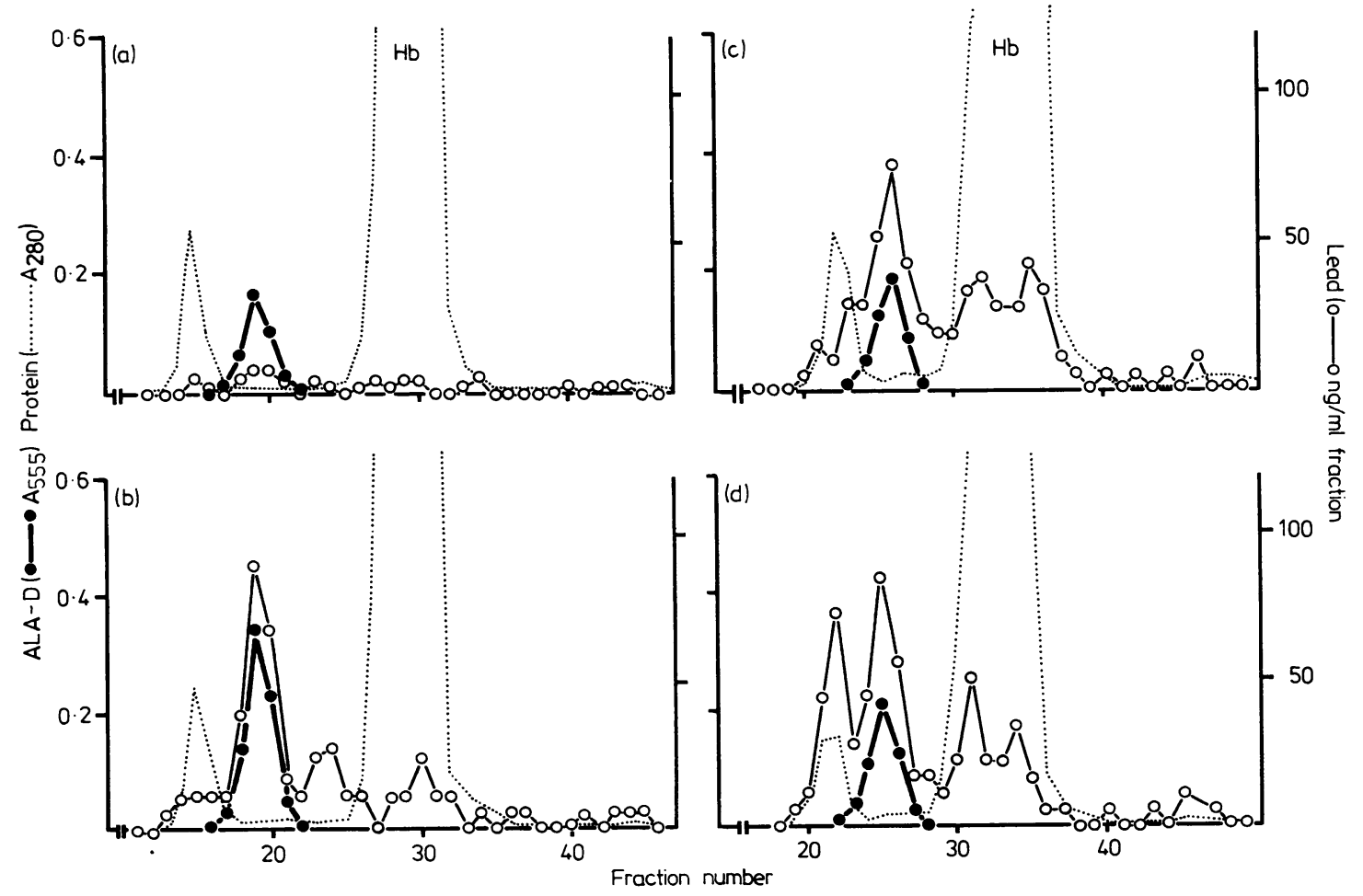

Fig 1 Distribution of in-vivo burdened lead among erythrocyte components. Blood lead concentrations of subjects $(a)-(d)$ were $10 \cdot 2,48 \cdot 6,69 \cdot 6$, and $76 \cdot 3 \mu \mathrm{g} / 100 \mathrm{~g}$ respectively. 
by the methods described above. ALA-D activity of the two types of ES sample was also determined with or without heating. ${ }^{18}$

\section{LEAD-BINDING TO WHOLE BLOOD}

Heparinised blood was obtained from normal donors with no history of exposure to lead. Four millilitres of blood were added to $1 \mathrm{ml}$ of lead acetate solutions $(0-7 \mu \mathrm{g} / \mathrm{ml}$ of $0.9 \% \mathrm{NaCl})$ and incubated at $37^{\circ} \mathrm{C}$ for 60 minutes and then at $4^{\circ} \mathrm{C}$ for 20 hours. All procedures for the preparation of each fraction were carried out at $4^{\circ} \mathrm{C}$. After centrifugation of lead-loaded blood, the packed erythrocytes were washed five times with cooled saline $(0.9 \%$ $\mathrm{NaCl}$ ); the original haematocrit value was restored with $40 \mathrm{mM}$ Tris- $\mathrm{HCl}$ buffer $\mathrm{pH} 7 \cdot 0$. Erythrocytes were completely lysed by sonicating, and ES was obtained by centrifugation in the manner described above. Altogether $2.5 \mathrm{ml}$ of ES was fractionated by passing through a Bio-gel A $1.5 \mathrm{~m}$ column $(1.6 \times$ $90 \mathrm{~cm}$ ), which had been equilibrated with $40 \mathrm{mM}$ Tris- $\mathrm{HCl}$ buffer $\mathrm{pH} 7 \cdot 0$ and eluted with the same buffer. Each fraction was collected in $4.7 \mathrm{ml}$ aliquots on which ALA-D activity and protein concentrations were determined. After the addition of $1.5 \mathrm{~N}$ $\mathrm{HClO}_{4}$ to each fraction (final $0.15 \mathrm{~N}$ ), the lead concentrations were directly determined using flameless atomic absorption spectrophotometer. Measurement of ALA-D activity of ES and its restoration by heat, zinc, or dithiothreitol were carried out by the method previously described..$^{18}$

\section{Results}

Figure 1 shows the Sephadex G-200 gel filtration chromatography of ES from a normal subject and

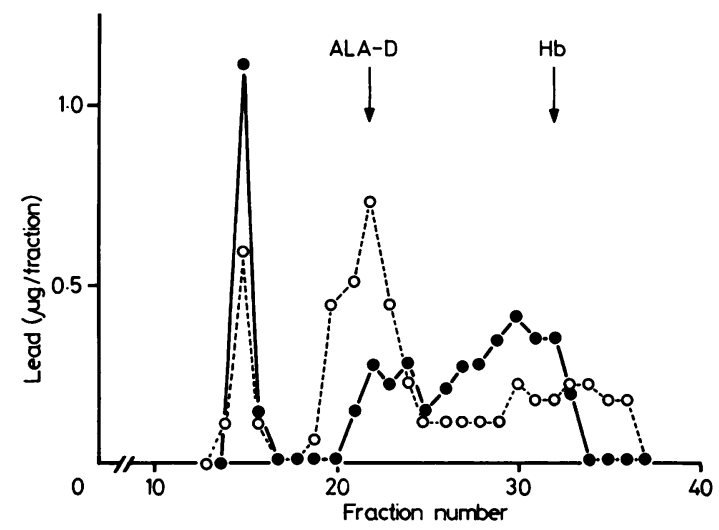

Fig 2 Distribution of lead loaded to erythrocyte lysate in vitro. Erythrocyte lysate was incubated with lead acetate $(50 \mu \mathrm{g} / 100 \mathrm{ml})$ for 5 minutes (- $\longrightarrow$ ) or 40 hours (-- O--) as described in materials and methods. from the lead workers. In fig 1(a) which shows the chromatography of ES from a normal subject there is no significant lead peak. By contrast, in figs 1(b)(d) there are three or four lead peaks, the largest of which corresponds with that of ALA-D activity. About half the lead in the ES from a worker (b) is found in a peak that exactly corresponds to the ALA-D activity, suggesting that proteins in ALA-D fraction have the highest affinity for lead. With the rise in blood lead concentrations (figs $1(\mathrm{c})$ and (d)), no more increase of lead can be seen in the ALA-D fraction proteins, while the lead in other fractions is increasing. These observations suggest that leadbinding to ALA-D fraction proteins attains a plateau at high concentrations of blood lead (over $70 \mu \mathrm{g} / 100 \mathrm{~g})$.

Figure 2 shows the gel filtration chromatography of lead bound to erythrocyte lysate. After 5 minutes' incubation of the lysate with lead acetate, lead found in ALA-D and the haemoglobin fractions are $21 \%$ and $41 \%$ respectively. After 40 hours' incubation, $43 \%$ and $27 \%$ of ES lead are found in the ALA-D and haemoglobin fractions respectively. After 40 hours' incubation, lead in the ALA-D fraction increased and that in the haemoglobin fraction decreased. The distribution pattern of lead after 40 hours' incubation was similar to that in fig 1 , indicating that it takes a long time for erythrocyte constituents to attain an equilibrium with added lead. Table 1 shows the ALA-D activity of ES; the lead concentrations of the different fractions are shown in fig 2. An increase in the amount of lead in the ALA-D fraction after 40 hours' incubation is associated with an increased inhibition of ALA-D activity. Based on these findings it appears that the lead responsible for inducing the inhibition of ALA-D is not bound to haemoglobin fraction proteins but to the ALA-D fraction proteins.

To examine further the relationship between ALA-D inhibition by lead and lead-binding to ALA-D fraction proteins, we carried out in-vitro experiments, in which blood from a normal subject was loaded with varying amounts of lead. In these experiments we incubated blood with lead at $37^{\circ} \mathrm{C}$ for 60 minutes and then at $4^{\circ} \mathrm{C}$ for 20 hours, where ALA-D inhibition attained a plateau (data not shown). Table 2 indicates the relation between the amount of loaded lead and lead absorption by erythrocytes in vitro. The percentage of lead absorbed by the ES decreases with increasing amounts of loaded lead, suggesting that the rate of lead incorporation into erythrocytes is decreased at a high dose level in vitro.

Figure 3 shows the distribution of varying amounts of lead that are loaded to erythrocytes in vitro (table 2). As the amount of lead is increasingly 
Table 1 ALA-D inhibition by lead acetate incubated for 5 minutes and 40 hours

\begin{tabular}{llllr}
\hline & \multicolumn{2}{l}{$A L A-D$ activity $\left(A_{55 s}\right)$} & VHE (\%) \\
\cline { 2 - 4 } & $N H$ & $(\%)$ & $H$ & \\
\hline Control & 0.280 & $(100)$ & 0.335 & 83.6 \\
Pb (5 min) & 0.208 & $(74 \cdot 3)$ & 0.201 & 104.0 \\
$\mathrm{~Pb}(40 \mathrm{~h})$ & 0.031 & $(11.5)$ & 0.200 & 15.5 \\
\hline
\end{tabular}

ES added distilled water instead of lead acetate was used as control. $\mathrm{Pb}(5 \mathrm{~min})$ and $\mathrm{Pb}(40 \mathrm{~h})$ were same as shown in fig 2 . NH and $\mathrm{H}$ were non-heated and heated $\left(60^{\circ} \mathrm{C}, 5 \mathrm{~min}\right)$ activity, respectively. VHE: value for heat effect $(\mathrm{NH} / \mathrm{H} \times 100) .{ }^{17}$

Table 2 Absorption of increasing amounts of lead acetate by erythrocytes in vitro

\begin{tabular}{lcccc}
\hline & $\begin{array}{l}\text { Loaded lead } \\
\text { acetate } \\
(\mu \mathrm{g} / 100 \mathrm{ml})\end{array}$ & $\begin{array}{c}\text { Lead concen- } \\
\text { trations in ES } \\
(\mu \mathrm{g} / 100 \mathrm{ml})\end{array}$ & $\begin{array}{l}\text { Absorbed lead }(\%) \\
\text { acetate } \\
(\mu \mathrm{g} / 100 \mathrm{ml})\end{array}$ \\
\hline I & 0 & $9 \cdot 1$ & 0 & - \\
II & 21 & 32.4 & 23.3 & 110.9 \\
III & 42 & 55.1 & 46.0 & 109.5 \\
IV & 63 & 64.9 & 55.8 & 88.6 \\
V & 105 & 81.9 & 72.8 & 69.3 \\
VI & 140 & 111.2 & 102.1 & 72.9 \\
\hline
\end{tabular}

loaded, four lead peaks appear in the gel filtration chromatography of ES-void volume, ALA-D, haemoglobin and low molecular weight fractions. These distribution patterns are similar to those seen in fig 1 . At comparatively low concentrations of lead (under $60 \mu \mathrm{g} / 100 \mathrm{ml} \mathrm{ES}$ ), the largest lead peak is found in the ALA-D fraction. At high levels (greater than $80 \mu \mathrm{g} / 100 \mathrm{ml}$ ) the lead peak corresponding to ALA-D activity is not raised further, although the amounts of lead in the other fractions are still increasing. These results are summarised in fig 4. Apparently lead-binding to ALA-D fraction proteins reaches saturation level at lead concentrations exceeding $80 \mu \mathrm{g} / 100 \mathrm{ml}$ ES.

Figure 5 shows the ALA-D activity of ES (table 2, figs 3,4$)$. The activity declines in a linear fashion as the ES lead concentration increases up to $60 \mu \mathrm{g} /$ $100 \mathrm{ml}$ but no further decline is found at lead concentrations exceeding $60 \mu \mathrm{g} / 100 \mathrm{ml}$. This is $20 \mu \mathrm{g} /$ $100 \mathrm{ml}$ lower than those resulting in saturation of ALA-D fraction proteins with lead (figs 3,4 ). These observations further confirm that most of the lead found in the ALA-D fraction is responsible for inducing ALA-D inhibition. The inhibited activity is
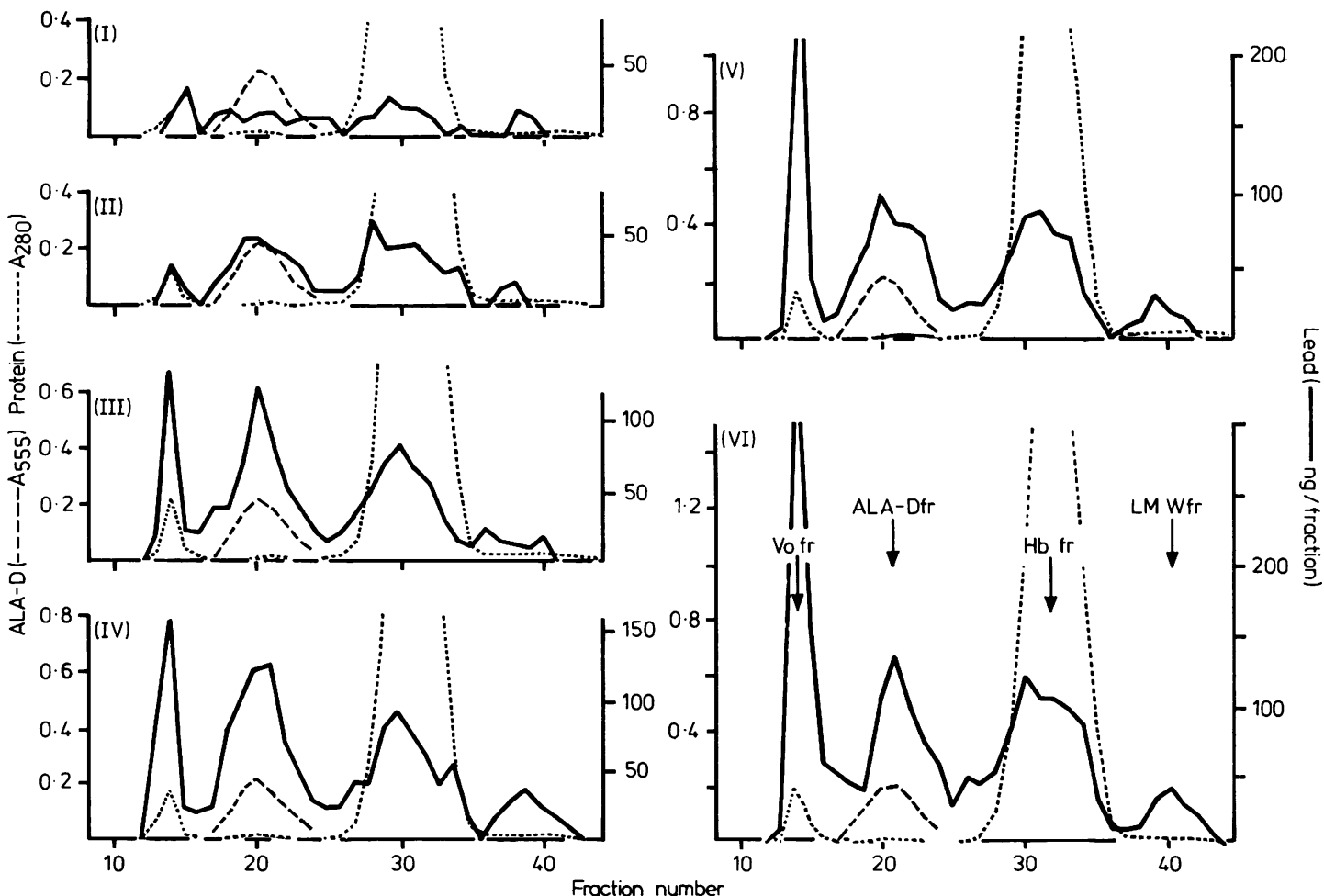

Fig 3 Distribution of increasing amounts of lead loaded to erythrocytes in vitro. Lead concentrations in ES of (I)-(VI) are indicated in table 2. Vo fr: void volume fraction, $A L A-D$ fr: $A L A-D$ fraction, $H b$ fr: haemoglobin fraction, LMW fr: low molecular weight fraction. 


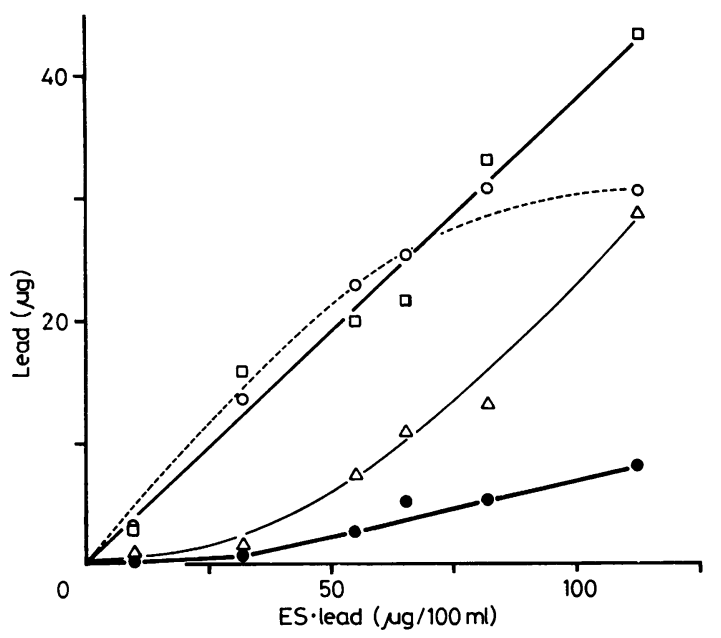

Fig 4 Relationship between ES lead concentration and lead in four fractions as shown in fig 3. Amounts of lead in four fractions were expressed as lead $(\mu \mathrm{g})$ originated from $100 \mathrm{ml}$ of ES. $\bigcirc: A L A-D$ fraction, $\square: H b$ fraction, $\triangle:$ void volume fraction, low molecular weight fraction.

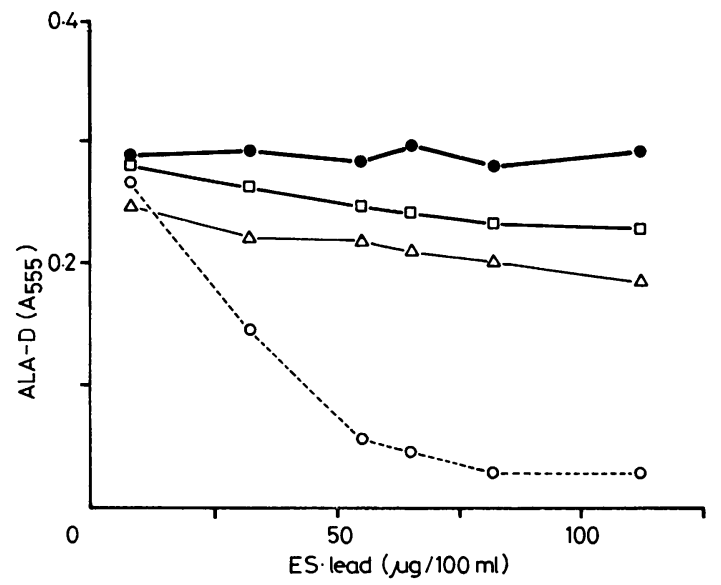

Fig $5 A L A-D$ inhibition by $E S$ lead and its restoration by three treatments. $\bigcirc:$ no treatment, $\bigcirc:$ zinc $(100 \mu M), \square$ : dithiothreitol $(10 \mathrm{mM}), \triangle$ : heat $\left(60^{\circ} \mathrm{C}, 5 \mathrm{~min}\right)$.

totally restored to the control level by zinc, while neither dithiothreitol nor heat is sufficient to restore the inhibition, especially at high concentrations of lead.

\section{Discussion}

This is the first report on the distribution of erythrocyte lead from lead workers in relation to ALA-D inhibition. We have shown that proteins in ALA-D fraction have the highest affinity for lead among erythrocyte components in vivo and in vitro. The only investigation that has dealt with erythrocyte lead-binding proteins from lead-exposed workers is that by Raghavan et al, ${ }^{5}$ who determined the lead content in four fractions of red blood cell haemolysate (haemoglobin lead, 10000 molecular weight fraction lead, free lead, and residual lead). In their experiments, the haemoglobin fraction contained about half the erythrocyte lead. Several workers ${ }^{7-9}$ using radioactive lead have noted that haemoglobin has a high affinity for lead in vitro. Ong and $\mathrm{Lee}^{9}$ concluded that haemoglobin is the principal molecule interacting with lead in erythrocytes. In their experiments the duration of incubation of erythrocytes with lead was two hours. Their results are actually coincident with ours as seen in fig 2 (5-minute incubation of lysate with lead). We have, however, confirmed that erythrocyte components are not equilibrated with lead added in vitro within two hours of incubation at $37^{\circ} \mathrm{C}$, because ALA-D inhibition by added lead does not attain the plateau level. ${ }^{19}$ After 40 hours' incubation of lysate with lead, ALA-D was almost completely inhibited (table 1), and the lead peak in ALA-D fraction was the most prominent (fig 2). This pattern of distribution of lead was similar to that found in ES from lead workers (fig 1). It takes 20-40 hours ${ }^{1019}$ for the erythrocyte constituents to be equilibrated with lead added in vitro, as seen in blood from lead-exposed workers.

In a previous paper ${ }^{10}$ we found that to induce or intensify the inhibition of ALA-D in vitro, it is necessary for the enzyme fraction to be preincubated with lead acetate and the erythrocyte factors in the haemoglobin fraction. The enzyme activity can be restored by gel filtration and reinhibited by preincubation with the haemoglobin fraction. The haemoglobin fraction containing bound lead also causes ALA-D inhibition if preincubated with a normal ALA-D fraction. The problem of whether the lead that causes ALA-D inhibition originates from the ALA-D fraction or the haemoglobin fraction has not been solved. The present study has shown that the lead which induces ALA-D inhibition is not bound to the factors in the haemoglobin fraction but to the ALA-D fraction proteins. Lead bound to the ALA-D fraction protein, however, cannot induce the inhibition unless it has been incubated with the factors. ${ }^{10}$

The inhibition of ALA-D by lead reaches a plateau at lead concentrations exceeding $60 \mu \mathrm{g} /$ $100 \mathrm{ml}$ ES, while the ALA-D fraction becomes saturated with lead at $80-110 \mu \mathrm{g} / 100 \mathrm{ml}$. The difference in these concentrations suggests that a small amount of lead $(20-40 \mu \mathrm{g} / 100 \mathrm{ml})$ might bind to the 
proteins other than ALA-D. At concentrations under $60 \mu \mathrm{g} / 100 \mathrm{ml}$, however, most of the lead found in the ALA-D fraction seems to be bound to ALA-D protein and is responsible for the inhibition in the presence of the factors. Thus the decrease in ALA-D activity is an indicator of lead saturation of ALA-D fraction proteins which have the highest affinity for lead, because the extent of ALA-D inhibition correlates with that of lead saturation of the fraction at low lead concentrations (figs 4,5). These results are consistent with those obtained from the determination of ALA-D activity in leadexposed workers. ${ }^{11-14}$

Data of the restoration experiments (fig 5) are also compatible with those previously reported..$^{10}$ Zinc completely restored the inhibition of ALA-D activity to the control level at wide range of lead concentrations; dithiothreitol and heat did not completely restore activity, especially at high concentrations of lead. The blood used for the present study was fresh, and the enzyme was thought not to be oxidised because the activity was slightly increased by dithiothreitol at a lead concentration of $9 \mu \mathrm{g} /$ $100 \mathrm{ml}$ (fig 5). In the previous experiment ${ }^{10}$ the extent of restoration by dithiothreitol was larger than that of zinc, because the enzyme was partly oxidised during purification. Zinc does not bind to the enzvme unless the essential cysteinyl residues are reduced..$^{20}$ Although zinc cannot restore the inactivation of ALA-D caused by oxidation, it is the only agent capable of fully restoring the inhibition due to lead.

Haemoglobin fraction proteins also have a high affinity for lead. ${ }^{921}$ We do not know whether or not all the lead in the haemoglobin fraction is bound to the haemoglobin molecules. The effect of lead on the haemoglobin fraction and on fractions other than ALA-D has not been clarified.

\section{References}

' Baloh RW. Laboratory diagnosis of increased lead absorption. Arch Environ Health 1974;28:198-208.

${ }^{2}$ Cavalleri A, Minoia C, Pozzoli L, Baruffini A. Determination of plasma lead levels in normal subjects and in lead-exposed workers. Br J Ind Med 1978;35:21-6.

${ }^{3}$ Goyer RA, Mushak P. Lead toxicity laboratory aspects. In: Advances in modern toxicology. Vol 2. Washington and London: Hemisphere Publishing Co, 1977:41-77.

4 Rosen JF, Zarate-Salvador C, Trinidad EE. Plasma lead levels in normal and lead-intoxicated children.J Pediatr 1974;84:45-8.

${ }^{5}$ Raghavan SRV, Culver BD, Gonick HC. Erythrocyte leadbinding protein after occupational exposure. I Relationship to lead toxicity. Environ Res 1980;22:264-70.

- Ong CN, Lee WR. Interaction of calcium and lead in human erythrocytes. Br J Ind Med 1980;37:70-7.

' Barltrop D, Smith A. Interaction of lead with erythrocytes. Experientia 1971;27:92-3.

B Bruenger FW, Stevens W, Stover BJ. The association of ${ }^{210} \mathrm{~Pb}$ with constituents of erythrocytes. Health Physics 1973;25:37-42.

- Ong CN, Lee WR. Distribution of lead-203 in human peripheral blood in vitro. Br J Ind Med 1980;37:78-84.

${ }^{10}$ Sakai T, Yanagihara S, Ushio K. Erythrocyte factors concerned in the inhibition of ALA-D by lead. $\mathrm{Br} J$ Ind Med 1981;38:268-74.

" Bonsignore D, Calissano P, Cartasegna C. A simple method for the determination of blood $\delta$-amino-levulinic-dehydrase. Med Lav 1965;56:199-205.

12 de Bruin A, Hoolboom H. Early signs of lead-exposure. A comparative study of laboratory tests. $\mathrm{Br} J$ Ind Med 1967;24:203-12.

${ }^{13}$ Nakao K, Wada O, Yano Y. $\delta$-aminolevulinic acid dehydratase activity in erythrocytes for the evaluation of lead poisoning. Clin Chim Acta 1968;19:319-25.

${ }^{14}$ Hernberg S, Nikkanen J, Mellin G, Lilius H. $\delta$-aminolevulinic acid dehydrase as a measure of lead exposure. Arch Environ Health 1970;21:140-5.

is Anderson PM, Desnick RJ. Purification and properties of $\delta$-aminolevulinate dehydrase from human erythrocytes. $J$ Biol Chem 1979;254:6924-30.

${ }^{16}$ Sakai T, Yanagihara S, Ushio K. Effect of metal ions on ALA-D activity in vitro and evaluation of lead-burden by zinc activation of ALA-D. Journal of Japan Accident Medical Association 1979;27:30-8.

17 Ushio K, Sakai T, Yanagihara S, Watanabe H. Properties of ALA-D ( $\delta$-aminolevulinic acid dehydratase) and the evaluation of lead exposure using heat activation. Japanese Journal of Industrial Health 1975;17:475-82.

18 Sakai T, Yanagihara S, Ushio K. Restoration of lead-inhibited 5-aminolevulinate dehydratase activity in whole blood by heat. zinc, and (or) dithiothreitol. Clin Chem 1980;26:625-8.

19 Sakai T, Niinuma Y, Yanagihara S, Ushio K. Effect of preincubation on ALA-D inhibition by added lead. Journal of Japan Accident Medical Association 1980;28:56-61.

:o Bevan DR, Bodlaender P, Shemin D. Mechanism of porphobilinogen synthase. Requirement of $\mathrm{Zn}^{2+}$ for enzyme activity. J Biol Chem 1980;255:2030-5.

${ }^{21}$ Ong CN, Lee WR. High affinity of lead for fetal haemoglobin. $\mathrm{Br}$ J Ind Med 1980;37:292-8. 